\title{
Strategic Planning as a Competitive Advantage by Using the BSC as a Management Tool: A Case Study in Application of Radioisotope Technology at IPEN
}

\author{
Imário Vieira ${ }^{1}$, Fernando Codelo Nascimento ${ }^{1}$ and Wilson Aparecido Parejo Calvo ${ }^{2}$ \\ 1. National Service for Industrial Apprenticeship (SENAI), SENAI Mario Amato School, Av. Vitória Maria Médici Ramos 330 , \\ 09861-000, São Bernardo do Campo/SP, Brazil \\ 2. Nuclear and Energy Research Institute (IPEN), National Nuclear Energy Commission (CNEN), Av. Professor Lineu Prestes 2242, \\ 05508-000, São Paulo/SP, Brazil
}

\begin{abstract}
Strategic planning is one of the most important management tools for organizational decision making. The nuclear area represents a segment of energy production used by many countries in America, Europe and Asia. It is known that in the future nuclear energy can be a major exit to the global energy crisis. The aim of this research was to use the BSC (Balanced Scorecard) as a strategic tool for decision making in a teaching and research institution of the nuclear area-IPEN (Nuclear and Energy Research Institute), located in the city of Sao Paulo, which belongs to the CNEN (National Nuclear Energy Commission) in Brazil. The methodology used in this academic doctoral study was a case study, which considered the period of research from December 2012 to December 2015. The main results expected from this case study are: the improvement of information flow, the view, the increased visibility of an organization providing education and especially research in relation to published works, increased interaction among IPEN and the main global research institutes and centers, increasing academic production of technical articles, indicator improvement, improving the monitoring of management actions, among others. Given the expected results one can conclude that this study will be of great value to the IPEN and also for the Brazilian energy sector, as it will allow and contribute to the dissemination and demystification of nuclear power as an energy source of mankind, its peaceful applications and for the management activity of knowledge and innovation production in the nuclear area of IPEN.
\end{abstract}

Key words: BSC, strategic planning, nuclear energy, radioisotope technology, IPEN.

\section{Introduction}

The theme presented in this article is the strategic planning and BSC (Balanced Scorecard), whose object of study a research institute and producer of radioactive sealed sources for industrial radiography, specifically, Iridium-192, Cobalt-60 and Selenium-75 in Radiation Technology Centre at IPEN.

The IPEN (Nuclear and Energy Research Institute) is a State of Sao Paulo autarchy and Brazilian institution, associated to the USP (University of Sao Paulo) for educational purposes, supported and administrated technical and financially by the CNEN

Corresponding author: Imário Vieira, Ph.D., research field: applications of nuclear technology-radioisotope technology.
(National Nuclear Energy Commission). It is recognized as a national leader institution in $R \& D$ areas of Radiopharmacy, Application of Ionizing Radiation, Nuclear Science and Technology, Nuclear Reactors and Fuel Cycle, Environmental Science and Technology, Renewable Energies, Materials and Nanotechnology, Biotechnology, Laser Technology and Education.

The Radiation Technology Centre at IPEN was founded in 1972, spreading and consolidating the techniques that lead with radiation technology and radioisotopes applications in Industry, Human Health, Agriculture and Environment Preservation in Brazil. The scientific knowledge production, human power resources, technology transfers and generation of 
products and services are aimed to various segments of the Brazilian society. Research and development, innovation, products and services have been carried out in this Centre, supporting the local industries and scientific communities in the use of the radiation technology.

Due to its mission "to disseminate and consolidate techniques leading to the use of the radiation technology and radioisotopes applications in Industry, Human Health, Agriculture and Environmental Preservation", nuclear technique applications areas, main activities and radioactive facilities are installed, such as, laboratories (industrial dosimetry, material characterizations and analyses, radioactive sources production and applications), gammacell, panoramic and multipurpose (37PBq) gamma irradiators and two industrial electron beam accelerators $(37.5 \mathrm{~kW}$ and $97.5 \mathrm{~kW})$.

The BSC is a performance measurement tool used in various sectors of the world market, both public and private. The BSC was created by Robert Kaplan and David Norton from Harvard Business School and "proposes monitoring of the strategic objectives of the organization using performance indicators" [1]. Performance indicators are nothing more than tools, "which aims to help verifying a situation and decision-making” [2].

For the implementation of this research a question was made: how to facilitate the visualization and measurement of past and future actions of strategic planning in order to improve the image and competitiveness of the Laboratory of Sealed Sources Production for Industrial Radiography, in Radiation Technology Centre at IPEN?

As a solution to the problem, it is proposed as a hypothesis, using the BSC as a strategic planning tool to improve the image and competitiveness in order to further strengthen the image of the Laboratory of Sealed Sources Production for Industrial Radiography at IPEN, given the current and fragile scenarios that a competitive and globalized world presents.
The overall objective of this study was to propose the implementation of a strategic plan guided by a valuation model and strategic tool, the BSC, in order to facilitate the visualization to the managers of the Radiation Technology Centre of what is essential and strategically critical for IPEN, based on the current institutional strategic plans.

Among the reasons for which the feasibility study carried out were a practical and easy viewing for monitoring a faster decision-making and helping the management process, increasing academic production of technical articles, indicator improvement, improving the monitoring of management actions, among others.

The work is relevant due to the fact to enable a possible use of this management tool in a public research institute.

The methodology used was a case study, given that there are no studies on this topic in the Laboratory of Sealed Sources Production for Industrial Radiography in Radiation Technology Centre at IPEN. Thus, knowing that the methods are the ways, "the procedures to be followed in conducting the research" [3], the methodology to be used in this $\mathrm{PhD}$ work is a case study and it will be held in the Radiation Technology Centre at IPEN.

Among the main instruments used for this research are technical articles, theses, dissertations, books, documents related to planning, technical reports and more.

\section{Bibliographic Search}

In order to provide a basis for the practical part of this research, key issues were addressed on the subject under study in order to build up a theoretical framework and facilitate the use of the BSC as a decision making tool.

\subsection{Strategic Planning and BSC}

Among the many challenges ahead for today's organizations in a globalized world are found: the 
evolution of management, the intensification of competition, and the consumers changing habits, the technological revolution in all sectors of the economy, connecting markets by Worldwide Web among others. It is important to mention that all of these challenges have required increasingly modern practices of planning and measurement of financial and non-financial performances in all organizations worldwide.

In order to further clarify the BSC, Fig. 1 shows challenges for the company before a globalized world.

In the XXI century, it is faster and faster the technological revolution that the world has been passing through, and in some specific cases, this revolution depends on the nuclear area which has brought these new technologies in last decades such as: cancer diagnostics and treatments, crosslinking of wire and cable, gemstone treatment, radiation sterilization, cultural heritage preservation, food irradiation, preservation of human tissues, wastewater treatment, radioactive sealed source for NDT (non-destructive testing) and many others. These new applications of nuclear area have brought changes in consumers' habits, and somehow, it contributes to a better acceptance that these consumers can no longer live without these new uses of nuclear technologies. Thus, the emergence of new areas of expertise in nuclear research has led to fiercer competition, especially with the breakdown of barriers in trade transactions because of the emergence of the
Worldwide Web. Therefore, the methods and management tools must also follow the speed of those changes.

However, although the challenges of the globalization are immense, "it is unlikely that a single country or region alone could control all technologies and skills to turn these opportunities into reality. These markets will emerge at different speed around the world" [4]. Therefore, who is a pioneer, will come out ahead of competitors and will gain greater market opportunities in a world with products and services arising from the nuclear area. Hence, there is no doubt about the importance of making a good planning.

\subsubsection{Planning}

In fact, the word planning, "is an integrated, formal and systematic method of decision making that seeks to ensure that organizations achieve their goals" [5].

The planning of actions has been present in human life since the dawn of mankind. In a turbulent environment and with so many global economic crisis it creates great challenges for managers around the world that have to plan better and better and even more efficiently and effectively in order to maximize the results of their organizations.

Planning is strategic because "the focus of action will seek to highlight the strengths of the company before its consumers and try to excel attacking the weaknesses of competitors" [6]. Thus, in this way, having a good strategy is the first step to remain effective in globalized world.

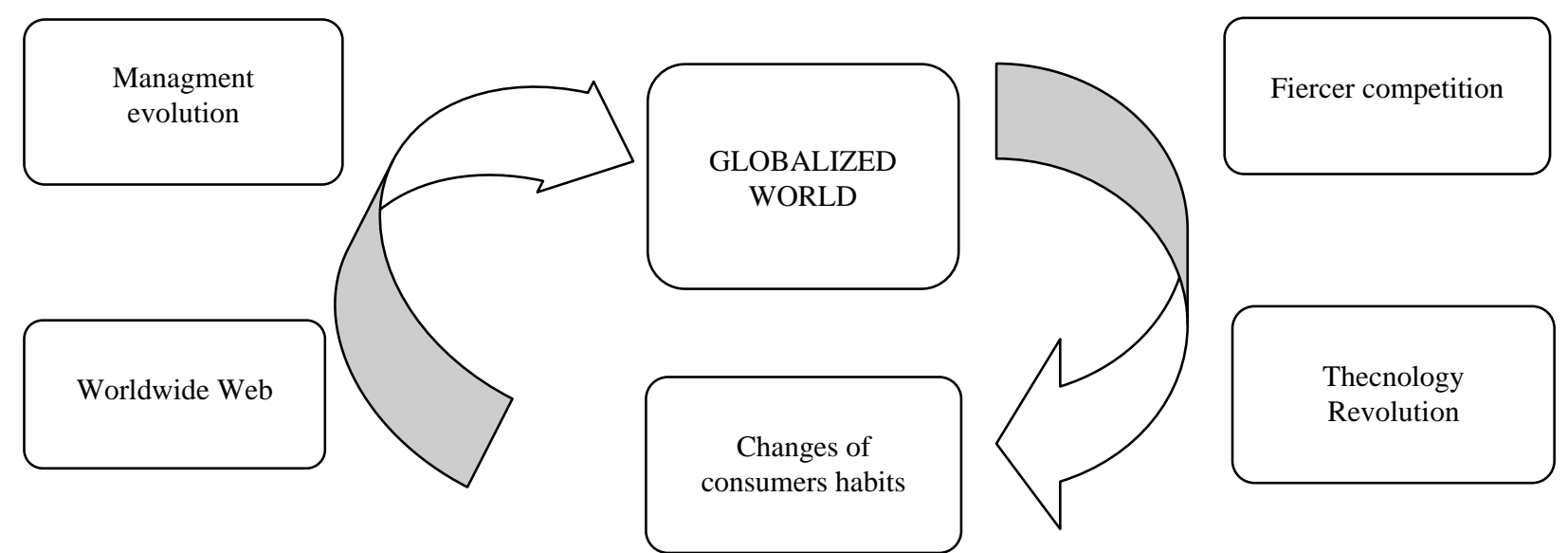

Fig. 1 Challenges for the company before the globalized world. Source: Vieira, Imário (2015). 


\subsubsection{Strategy}

Hamel and Prahalad (2005) define the strategy as the construction process of the future by leveraging core competencies of the company. It is related to the "art of properly using the physical, financial and human resources in order to minimizing problems and maximizing opportunities” [1].

The well-planned strategies used in the past to win wars and military confrontations, are now used to overcome the enemy in another kind of war and confrontation, in other words, the maintenance and market share of their markets. Therefore, establishing a competitive strategy is a survival factor. So, it is worth pointing out that the basic concept of strategy is directly linked to business and the environment in which it lies [1].

Strategists (directors and managers of organizations) have to innovate all the time with a well thought strategic planning in order to survive in this new market of uncertainty that presents itself in the twenty-first century.

\subsubsection{Strategic Planning}

Strategic planning is an administrative technique that, through the analysis of an organization's environment, creates awareness of its opportunities and threats of their strengths and weaknesses for the fulfillment of its mission and through this consciousness, sets the direction that the organization must take to get advantages of the opportunities and avoid risks [6].

Fig. 2 shows some of the basic requirements to have a good strategic planning.

There are many requirements of a strategic planning, the manager needs to: a) knowing its company well, your strengths and weaknesses, in order to make good use of their competitive advantages that your organization have and make the necessary changes to correct possible flaws; b) knowing its main competitors, its threats and opportunities, in order to avoid losing market share by having well-planned strategies; c) discovering what competitors values most and what are their strategies, this information will be of great help to correct strategic plans; d) anticipating trends of markets in which it operates, because by doing so, it will put the organization ahead of its competitors; e) using new technologies, since the current market demands for innovative technologies; and f) finally, the manager needs to have

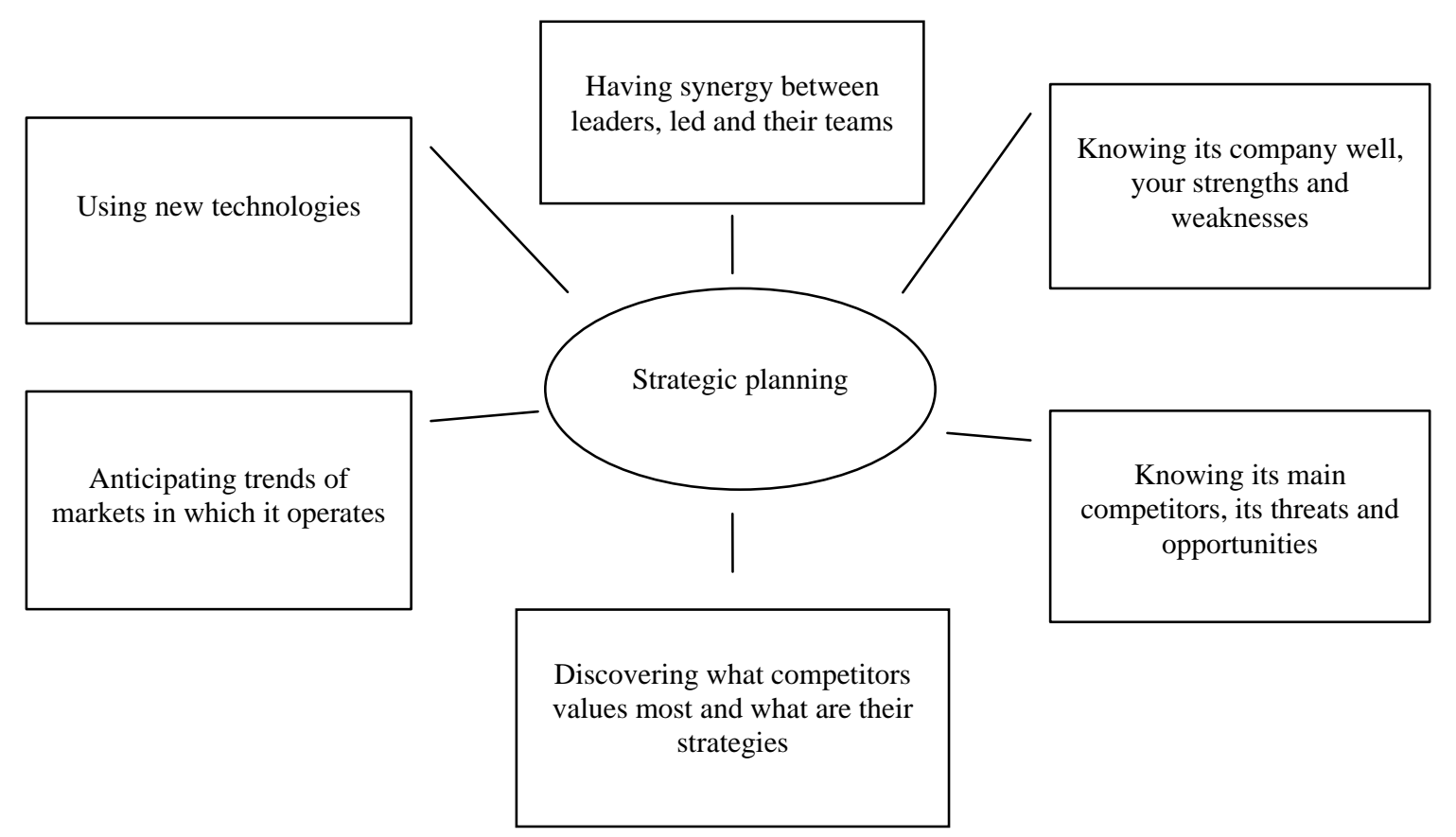

Fig. 2 Demands of a good strategic planning. Source: Vieira, Imário (2015). 
synergy among them, the leaders, led and their teams, well-defining which strategy is short, medium and long term, because all organization members have to be lined up and implement the necessary actions.

However, it is noteworthy that in order to achieve the results, you will need good strategic planning and good strategic management, because there are differences between one concept and another. Table 1 shows some differences between Strategic Planning and Strategic Management.

Doing strategic planning is not as simple as it seems, since it requires many discoveries, knowledge, because it deals with facts, ideas and probabilities. Thus, Table 1 shows that while the strategic plan gives direction that the company or organization must follow through a strategic plan, strategic management sets out the actions to be taken to ensure that, what was planned at the strategic level, can be put into practice, without forgetting to take a good care of the relationship and internal integration of the organization in the achievement of a new attitude towards the actions proposed by the strategic planning. Thus, an important step to get success is to have good performance indicators.

\subsubsection{Performance Indicators}

According to NBR 16001:2012, indicator is a qualitative and quantitative information related to the organization, and it can be used to monitor or evaluate the achievement of the objectives [7]. Good indicators develop a leading role in society, assisting in decision making [2].

The choice of good indicators is the paramount for BSC fulfilling its purpose of managing the business strategy and preparing a good BSC.

\subsubsection{The BSC}

There are several ways of defining the BSC, according to Silva (2012), it is an information system for management of business strategy [1]. On the other hand, Mansur (2008) defines BSC as a system of performance measurement considering the results and causes [8].

However, Kaplan and Norton said that, initially the BSC was considered only as a performance measurement system, but subsequently, organizations began to implement it as an instrument for monitoring the company's strategy, electing indicators based on organizational strategy [9].

Therefore, to achieve the expected results in the selection of relevant performance, indicators for the company are essential to the success of strategic planning.

Strategic planning has several tools to evaluate organizational performance, one of the best known is the BSC, which is an integrated system for managing and implementing the company's strategy, and its purpose is to translate the mission and strategy into a comprehensive set of performance measures that provides the basis for a measurement system and strategic management [11].

So, it is worth pointing out that, BSC, besides translating the mission and strategy into a measurable performance, it not only provides a financial analysis, but also includes other operational performance of spheres such as customer satisfaction, innovation, participation, among other things [9].

Fig. 3 shows the perspectives of the BSC, as a performance management tool for organizations.

So, it is important to say that, BSC serves to integrate

Table 1 Differences between Strategic Planning and Strategic Management.

\begin{tabular}{ll}
\hline Strategic Planning & Strategic Management \\
\hline Takes a position in relation to the environment & Takes into account the strategic capability \\
Deals with facts, ideas and probabilities & Aggregates the aspirations of people in the fast organizational changes \\
Ends with a strategic plan & Reaches a new behavior \\
It is a planning system & It is an action system \\
\hline
\end{tabular}

Source: GAJ, Luis (1995) [10]. 


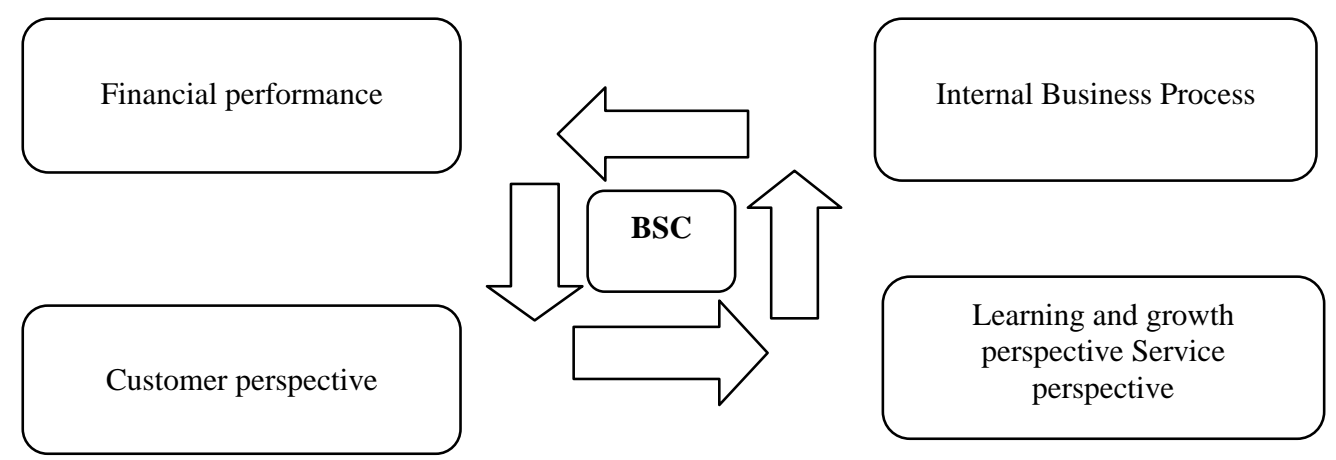

Fig. 3 The four perspectives of BSC. Source: Vieira, Imário (2015).

the company's vision at all levels (strategic, tactical and operational) making use of four perspectives: "financial or results, customers or markets, internal processes, learning and growth” [11].

\subsection{Strengthening the Image and Adding Value to the} Market and Customers

It is worth remembering that, in the XXI century, modern marketing management reports that, customers of the contemporary world, no longer buy goods or hire services without first thinking about the values that are behind them, because who does not think this way, will be walking in the opposite direction of history, because customers do not only buy goods or hire services, they also buy the benefits that the goods and services have to offer. They buy offers consisting of goods, services, information, personal care and other components. Such offers provide them with services, and those services are perceived by clients in the offer that creates value for them [12].

In this sense, the modern marketing points out to another consideration of value ${ }^{1}$ [13], because to this aspect of management, the value, "is not only the allocated financial equivalent directly to a product or service, but the appearance or fundamental aspects valued by consumers, both in the product as in the whole process" $[14,15]$.

The Fig. 4 shows the concept of value and the

\footnotetext{
1 For marketing, value is how the consumer evaluates a product or service, that is, they are the set of technical benefits, service, economic and social [13].
}

benefits it brings to customers.

So, based on the facts observed, it can be concluded that customers buy "values", and before they even purchase goods and services of an organization, a lot of these clients, mainly from rich and emerging countries, want to know what "values", what benefits (technical, service, economic, social and others) are behind the companies that provide the goods and services they consume.

Therefore, it is strategic for any organization to identify what customer values most, what are benefits that they want to get when buying its products and services, in order to not only enchant, but surprise consumers and by doing so, it improves the image that an organization has in consumer' minds.

It is important to mention that, it is imperative for organizations of the twenty-first century, which are embedded in a global market and in an extremely tough competition, make a profound review of its strategic planning, marketing and management processes in order to remain competitive within the markets they are in and improve their image adding value to its products and services in order to increase their market share.

\section{Methodology}

First, it was identified the need to disclose the methodology used for the implementation of the case study and literature necessary to give the conceptual decision support in practice. Once developed the model and reviewed the studies that directly or indirectly deal with the object of this research in order 


\begin{tabular}{|c|}
\hline The value for a client \\
\hline The value is how a consumer evaluates the product or service \\
\hline
\end{tabular}

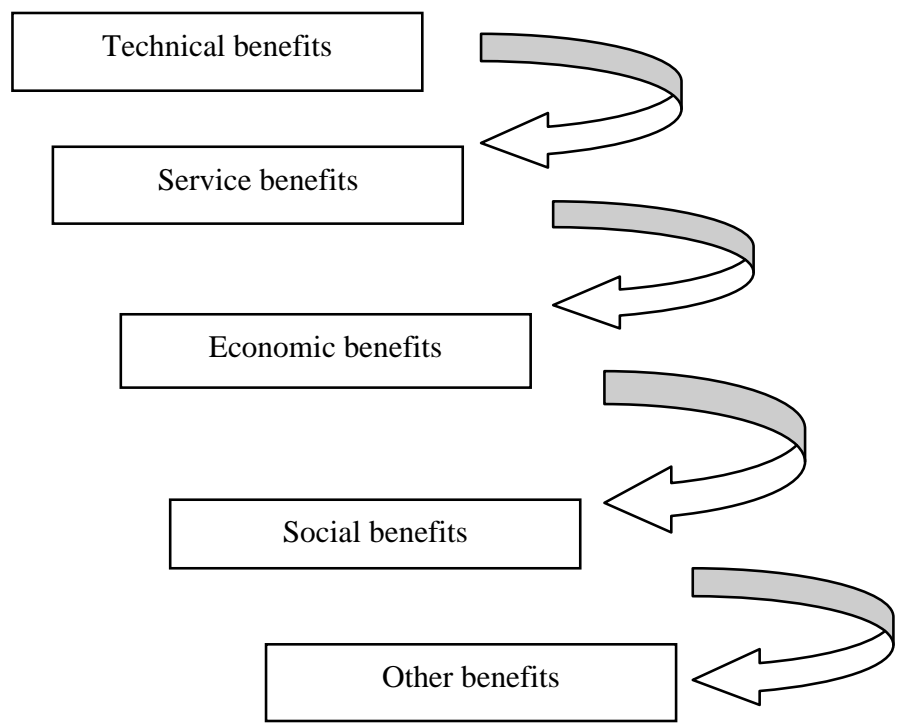

Fig. 4 What is valued to a customer in XXI century? Source: Adapted from COBRA (2006).

to illustrate its use, a field survey was conducted, and subsequently, the procedures used to carry out this work.

\subsection{Materials}

For the implementation of this study we used the BSC, as a decision-making tool and were used in this doctoral research:

(a) Interviews with managers of the Laboratory of Sealed Sources Production for Industrial Radiography, Radiation Technology Center, Commercial Management and Boards of Products and Services, Planning and Management from this Institute (IPEN);

(b) Performance indicators that were created through the BSC tool that would be used in the analyzes and proposals, becoming so, an additional strategic tool for the analysis of the capabilities and limitations of the Laboratory of Sealed Sources Production for Industrial Radiography, in Radiation Technology Center at IPEN;

(c) Reports and instruction manuals for professionals, among others; (d) Documentary research, based on the study of documents recorded at Radiation Technology Centre, such as technical reports, strategic plans of the organization, among other documents and events that are part of the everyday actions in IPEN and Databases and technical collections (books, articles, theses and dissertations).

\subsection{Methods}

The procedures performed in the research execution are described on subsections that follow:

(A) Critical analysis of the Strategic Plans

A critical analysis was promoted in order to get an understanding and critical analysis of the business drivers and future vision based on the IPEN Strategic Plan for the years 2012 and 2015 in order to show how they work with the indicators.

(B) Separation of the main indicators for the preparation of new draft performance indicators

This stage, involved the separation of the indicators used in the strategic plans of IPEN for the years of 2012 and 2015, in order to allocate them in the four 
dimensions of BSC (financial, internal process, customer and learning and growth perspectives).

(C) Choice of indicators

The selection and proposal of the main indicators for the BSC was an important stage because it has shown relational and not absolute indicators in a simple and practical way in order to promote a comparison between these indicators.

(D) Proposition of the new indicators

Another important part was the proposition of this new way to analyze the strategies of the institute's leaders for next year using this new model of indicators as a decision making tool, the BSC, if approved by the board of directors of the institute.

(E) Monitoring of new performance indicators

Monitoring these new indicators is the responsibility of the top managers of the CTR (monthly and annually), and may be extended to other research centers of IPEN on its various hierarchical levels of it.

\section{Discussion and Analysis of Results}

This research was conducted as an experimental basis, given that there were no studies on this topic in the Laboratory of Sealed Sources Production for Industrial Radiography at Radiation Technology Center.

This laboratory has been in operation since 1983 to meet the demands for the provision of consultancy services, production and marketing of radioactive sealed sources. It is part of the Radiation Technology Centre at IPEN.

The Laboratory of Sealed Sources Production for Industrial Radiography, located at IPEN is responsible for gamma irradiator inspections the production and of more than 300 sealed sources of Iridium-192 and Cobalt-60 annually. Besides, this laboratory supplied 12 sealed sources of Selenium-75 that were distributed to GammaMat and Sentinel irradiators in 2014. Up to this date, it had distributed 252 sealed sources of Iridium-192 in 2015. The laboratory has prospects of providing 350 sealed sources Iridium-192 for the year of 2016 [16].

It should be noted that according to the Strategic IPEN Plan (2014), the main performance monitoring mechanism provided by IPEN to its maintainer, the CNEN, was in first place, the indicators sent monthly to monitor the actions of the Long-Term Plan (PPA) in Brazil, and secondly, the annual indicators that make up the year's performance for all indicators and including detailed qualitative information of PPA actions.

Therefore, when using the term "indicators", it is necessary the usage of them not only in absolute way to promote an analysis of performance as currently used by IPEN, but in a relational way, using indicators that make comparisons such as production of scientific papers per student of master's and doctorate, attendance of seminars and conferences per master and doctoral students, and research compiled by patents registered with the INPI (National Institute of Industrial Property), among others. Based on this, it was elaborated a proposal with some relational indicators such as shown in Table 2.

Thus, it is shown in Table 2 that the proposal of these new indicators.

It is worth pointing out that, indicators which compare data, or relational indicators as shown in Table 2, are much more practical and easier for the visualization of what has been done and what still remains to be done in order to improve performance of an organization.

Main results of this study: an improvement of the flow of information inside and outside the institute (IPEN); an easy viewing of these indicators presented in a comparative or relational form, which gives higher subsidies for decision making for both tactical and strategic level managers. It also shows for its employees and for society actions that were taken and the progress that Brazilian research institute has had in a period of time. One of the consequences of these small changes in the way of presenting its main indicators 
Table 2 Proposal of new indicators (relational ones).

\begin{tabular}{|c|c|c|}
\hline Area & $\begin{array}{l}\text { Indicators } \\
(\times 100 \%)\end{array}$ & Managing report page \\
\hline \multicolumn{3}{|l|}{ A) Financial } \\
\hline & Total turnover of the previous year/total revenue of the current year & 32 \\
\hline & Previous received total assets $\mathrm{x}$ total funds received in the current year & 32 \\
\hline & Funding agencies capture last year/current year & 32 \\
\hline \multicolumn{3}{|l|}{ B) Internal Process } \\
\hline \multirow[t]{11}{*}{ Teaching } & Number of Doctors/publications in journals, books, others & 9 \\
\hline & Number of Masters/publications in journals, books, others & 9 \\
\hline & Number of experts/publications in journals, books, others & 9 \\
\hline & Number of employees with higher level/publications in journals, books, others & 9 \\
\hline & $\begin{array}{l}\text { Number of articles published in international periodicals of the previous year/ } \\
\text { current year }\end{array}$ & 32 \\
\hline & $\begin{array}{l}\text { Number of full papers published in proceedings of international scientific events } \\
\text { of the previous year/current }\end{array}$ & 32 \\
\hline & Patent applications in Brazil/Number of research carried out & 32 \\
\hline & Patent applications abroad/Number of research carried out & 32 \\
\hline & $\begin{array}{l}\text { Number of master's and doctoral guidelines (completed)/number and teachers } \\
\text { and doctors }\end{array}$ & 32 \\
\hline & $\begin{array}{l}\text { Number of completed guidelines (scientific initiation, master's and doctoral)/ } \\
\text { number of masters and doctors }\end{array}$ & \\
\hline & $\begin{array}{l}\text { Number of completed post-docs/students that have entered in the Post-doc } \\
\text { program }\end{array}$ & 32 \\
\hline Awards & External awards o nuclear field/external awards received & 32 \\
\hline Technology & $\begin{array}{l}\text { Number of technology developed in the previous year/number of technology } \\
\text { developed in the current year }\end{array}$ & 34 \\
\hline C) Market and clientes & Market share in radiopharmaceuticals in Brazil last year/current year & 34 \\
\hline \multirow[t]{2}{*}{$\begin{array}{l}\text { D) Learning and growth } \\
\text {-Services }\end{array}$} & Requested products and services/requests attended & 34 \\
\hline & Number of new products and services sold in the previous year/current year & 34 \\
\hline
\end{tabular}

Source: Vieira, Imário (2015).

was the alignment of strategies around the pursuit of better results year by year and thus, by showing them in a comparative way; it facilitates the viewing of improvements and deteriorations that the institute has had. Another consequence of this change is the increasing visibility of this educational and research institute, especially, in relation to research published, increased interaction between the IPEN and the world's leading research institutes and centers, increasing academic production of technical articles, among others.

\section{Conclusions}

The aim of this research was a proposition of the Balanced Scorecard as a strategic tool for decision making in a teaching and research institute (IPEN) in the nuclear area, associated to the USP (University of Sao Paulo) for educational purposes in Brazil. Moreover, this proposition has initiated a debate on the importance of adapting the BSC for the public sector and research institute facilitating the visualization of the actions taken and the future ones in a simple and understandable way for all stakeholders inside and outside this institute.

Given the expected and obtained results, it concluded that this study was and will be of great value to the IPEN and also for the Brazilian nuclear energy sector, showing how practical and easy it can be its management, using small changes such as the adoption of the BSC in their management and strategic practices.

The use of these indicators will facilitate a faster 
decision making process and it also contributes to the dissemination and demystification of nuclear energy and applications of nuclear technology, in addition to showing society how public money has been used on developing new technologies, giving indicators of number of research carried out in Radiation Technology Center at IPEN and number of technology developed related to nuclear area in diagnoses and treatments against cancer, food processing, preservation of tissues to be used in human transplants and burned, and not only as an energy source for mankind.

This study also showed through actions that use the BSC as an important tool for the management and accountability, can contribute to a greater visualization of what has been done by this institute (IPEN) during the period provided by such indicators.

Finally, it is interesting to note that there is no need for profound changes in any organization in order to show that it is possible to promote administrative and strategic modernization. The BSC tool is also a provision of cost to society showing through indicators what this Laboratory of Sealed Sources Production for Industrial Radiography, specifically, Radiation Technology Centre at IPEN has been doing with the public money.

\section{Acknowledgements}

I would like to thank my supervisor and mentor Wilson Aparecido Parejo Calvo and a friend Fernando Nascimento Codelo for the great help, trust and suggestions for the completion of another life project.

I thank also the IPEN, particularly the Radiation Technology Centre and staff who helped me in providing data for the preparation of this research, with important data for my analysis and results and everyone who directly or indirectly have contributed to my doctoral research.

\section{References}

[1] Silva, R. 2012. Balanced Scorecard-BSC: gestão do ensino superior, gestão profissionalizada e qualidade de ensino para instituições de ensino superior privado. $1^{\text {a }}$ ed. Curitiba: Juruá, 1-97.

[2] Padilha, M. 2015. "Luiza de Moraes Leonel; NASCIMENTO, Fernando Codelo.” Indicadores de sustentabilidade nos processos industriais. São Paulo: SENAI, 37-9.

[3] Gil, A. C. 2009. Como elaborar projetos de pesquisa. 4. ed. São Paulo: Atlas, 162.

[4] Hammei, G., and Prahalad, C. K. 2005. Competindo pelo futuro. São Paulo: Elsevier, 32.

[5] Chiavenatto, I. 2014. Introdução à teoria geral da administração. São Paulo: Manole.

[6] Yamaguti, C. L. 2006. “Planejamento estratégico.” In Administração para não administradores, edited by Kuazaki, E. São Paulo: Saraiva, 293-333.

[7] ABNT-Associação Brasileira de Normas Técnicas. NBR 16004: 2012. Responsabilidade social-sistema de gestão-requisitos. Rio de Janeiro: ABNT, 44.

[8] Mansur, R. 2008. Balanced scorecard: revelando SEPV-estudo de casos brasileiros. São Paulo: Ciência Moderna, 2.

[9] Kaplan, R. S., and Norton, D. P. 2004. Mapas estratégicos: convertendo ativos intangíveis em resultados tangíveis. $4^{\mathrm{a}}$ ed. Rio de Janeiro: Elservier.

[10] Gaj, L. 1995. Administração estratégica. São Paulo: Ática, 23.

[11] Gassenferth, W., Krause, W., and Machado, M. A. S. 2012. Gestão empresarial em gotas: agite depois de ler. São Paulo: Cengage, 120.

[12] Grönroos, C. 2009. Marketing: gerenciamento e serviços. 3. ed. São Paulo: Campus, 4.

[13] Cobra, M. 2006. Marketing básico. São Paulo: Atlas, 506.

[14] Las, C., and Alexandre, L. 2006. Administração de Marketing: conceitos, planejamento e aplicações à realidade brasileira. São Paulo: Atlas, 21.

[15] Las, C., and Alexandre, L. 2012. Excelência em atendimento ao cliente: atendimento e serviço ao cliente como fator estratégico e diferencial competitivo. São Paulo: Makron Books, 54.

[16] IPEN, Radiation Technology Centre. 2012. Fontes radioativas seladas industriais. São Paulo: IPEN. (Catálogo comercial). 